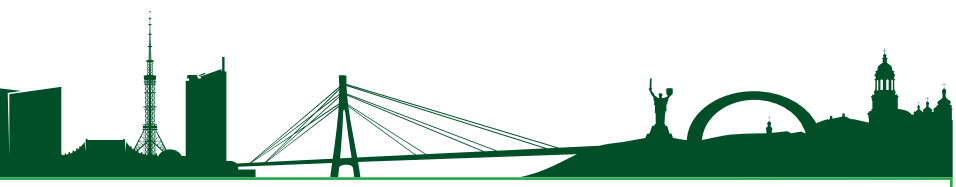

\title{
ABTOP
}

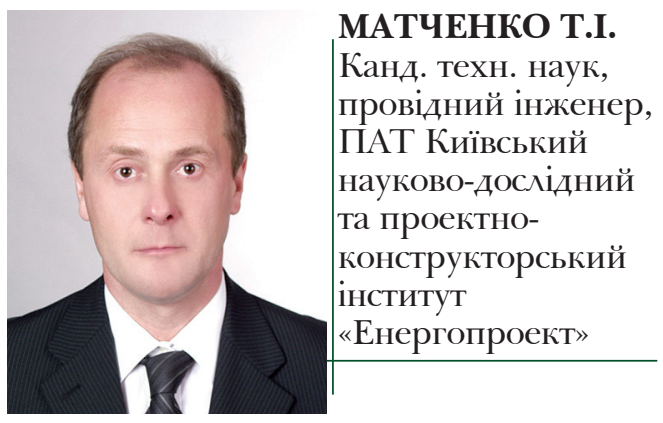

\section{РОЗРАХУНОК БАЛОК КРАНОВИХ КОАІЙ, ЩО ЗНАХОДЯТЬСЯ В ЕКСПАУАТАЦЇ̈, НА СТАТИЧНУ МІЦНІСТЬ, ОПІР КРИХКОМУ РУЙНУВАННЮ ТА ВИТРИВАЛІСТЬ}

УДК 624.015:624.023:620.19

\section{АНОТАЦІЯ}

Викладено співвідношення для розрахунку на статичну мічність, опір крихкому руйнуванню та витривалість балок кранових колій, що знаходяться в експлуатаий $i$ мають пошкодження та трішини.

Results for the calculation of the ratio of the static strength, resistance to brittle fracture and endurance crane girders in service and having damage and cracks are presented.

\section{КЛЮЧОВІ СЛОВА}

металоконструкції, балки кранових колій, тріщини, крихка міцність

\section{ВСТУП}

У випадку оцінки надійності та ресурсу сталевих балок кранових колій (кранових рейок), що знаходяться в експлуатації і ресурс яких збігає, необхідно виконати розрахункове обгрунтування міцності і стійкості балок кранових колій з урахуванням накопичених пошкоджень за час їх експлуатації. При цьому розрахункове обгрунтування повинно задовольняти вимогам нормативних документів [1, 2]. У відповідності з п.1 [1] державні будівельні норми [1] встановлюють вимоги до проектування сталевих конструкцій, у тому числі при їх зведенні, реконструкції та ремонті, а також при визначенні придатності до експлуатації існуючих конструкцій, але в [1] при визначенні міцності і стійкості елементів балок кранових колій відсутні залежності параметрів як функцій 


\section{WII 1 Malm}

часу експлуатації, не враховуються параметри пошкоджень та механізми деградації. В [2] в розділі «Розрахункова оцінка» наведено співвідношення для визначення несучої здатності і стійкості елементів конструкцій з урахуванням корозії, послаблень у вигляді вирізів, підрізів, зміни стрілки викривлення і таке інше. В $[1,2]$ не розглядається опір крихкому руйнуванню балок кранових колій.

Ціль цієї роботи - викласти співвідношення для оцінки статичної міцності, стійкості, опору крихкому руйнуванню балок кранових колій, що не вступають в протиріччя зі співвідношеннями [1], але їх доповнюють.

В цій роботі використано перелік розділів, формул, таблиць і рисунків такий, що співпадає 3 подібними в [1].

\section{РОЗРАХУНОК НА МІЦНІСТЬ БАЛОК СУЦІАЬНОГО ПЕРЕРІЗУ ДАЯ КРАНОВИХ КОАІЙ, ЩО ЗНАХОДЯТЬСЯ В ЕКСПАУАТАЦІї}

9.3.1 Розрахунок на міцність балок кранових колій, як правило, слід виконувати відповідно до вимог п. 7 на дію вертикальних і горизонтальних навантажень, визначених згідно 3 ДБН В.1.2-2:2006. Для балок двотаврового перерізу безгальмових конструкцій згинальний момент $M_{y}$ у горизонтальній площині повинен бути повністю сприйнятий перерізом верхнього поясу балки.

При розрахунку двотаврових балок кранових колій за формулою (9.3)

- при дії згинальних моментів $M_{x}(t)$ і $M_{y}(t)$ у двох головних площинах:

$$
\begin{gathered}
\frac{\gamma_{n} \times M_{x}(t) \times y}{\gamma_{C} \times I_{x n} \times\left(1-\omega(t)_{I}\right) \times R_{y} \times\left(1-\omega(t)_{R}\right)} \pm \\
\pm \frac{\gamma_{n} \times M_{y}(t) \times x}{\gamma_{C} \times I_{y n} \times\left(1-\omega(t)_{I}\right) \times R_{y} \times\left(1-\omega(t)_{R}\right)} \leq 1
\end{gathered}
$$

для кранів груп режимів роботи 1 K - 5К за ГОСТ 25546 допускається враховувати розвиток обмежених пластичних деформацій шляхом множення значення $I_{x n}$ на коефіцієнт 1,05 при $\alpha_{f} \leq 1$ і множення значення $I_{y n}$ на коефіцієнт 1,15 .

9.3.2 Розрахунок на міцність стінок балок кранових колій (за винятком балок, що розраховуються на утомленість, для кранів груп режимів роботи 7 К цехах металургійних виробництв і 8 К за ГОСТ 25546) необхідно виконувати за формулою (9.4), де $x$ і $y$ - відстані від головних осей інерції до точки перерізу, що розглядається;

- у загальному випадку

$$
\frac{0,87\left(\sigma_{x}^{2}-\sigma_{x} \sigma_{y}+\sigma_{y}^{2}+3 \tau_{x y}^{2}\right)^{1 / 2}}{R_{y}\left(1-\omega(t)_{R}\right) \gamma_{C}} \leq 1,
$$

де $\sigma_{x}=M(t) \times y /\left[I_{x n}\left(1-\omega(t)_{I}\right)\right]$ - нормальні напруження у серединній площині стінки, спрямовані паралельно до поздовжньої осі балки; $M(t)$ - згинаючий момент на час $t$; $Q(t)$ - поперечна сила (сила зсуву) на час $t$; $\sigma_{y}-$ те ж саме, спрямовані перпендикулярно до поздовжньої осі балки, у тому числі $\sigma_{l o c}$, що обчислюються за формулою (9.7) [1]:

$$
\tau_{x y}=Q_{y}(t) \times S_{x} \times\left(1-\omega(t)_{s}\right) /\left[I_{x} \times\left(1-\omega(t)_{I}\right) \times t_{W}\right],
$$

$\tau_{x y}$ - дотичні напруження у розглядуваній точці стінки балки.

Розрахунок на опір крихкому руйнуванню балок $з$ тріщинами в розтягнутому волокні, як показано на рис. 1 у розрахункових перерізах 1-го класу необхідно виконувати за формулами:

- при дії згинального моменту $M(t)$ в одній з головних площин:

$$
\frac{\gamma_{n} \times M(t) \times 1,12 \times(\pi \times L)^{1 / 2}}{W_{n, \text { min }} \times\left(1-\omega(t)_{W}\right) \times\left[K_{I C}\right] \times\left(1-\omega(t)_{K I C}\right) \times \gamma_{C}} \leq 1
$$

- при дії поперечної сили $Q(t)$, що спрямована паралельно серединній площині стінки з тріщинами:

$$
\frac{\gamma_{n} \times Q(t) \times S \times\left(1-\omega(t)_{S}\right) \times 1,12 \times(\pi \times L)^{1 / 2}}{I \times\left(1-\omega(t)_{I}\right) \times t_{W} \times\left[K_{I I I C}\right] \times\left(1-\omega(t)_{K I I I C}\right) \times \gamma_{C}} \leq 1
$$

- при дії згинальних моментів $M_{x}(t)$ і $M_{y}(t)$ у двох головних площинах:

$$
\begin{gathered}
\frac{\gamma_{n} \times M_{x}(t) \times y \times 1,12 \times(\pi \times L)^{1 / 2}}{I_{x n} \times\left(1-\omega(t)_{I}\right) \times\left[K_{I C}\right] \times\left(1-\omega(t)_{K I C}\right) \times \gamma_{C}} \pm \\
\pm \frac{\gamma_{n} \times M_{y}(t) \times x \times 1,12 \times(\pi \times L)^{1 / 2}}{I_{y n} \times\left(1-\omega(t)_{I}\right) \times\left[K_{I C}\right] \times\left(1-\omega(t)_{K I C}\right) \times \gamma_{C}} \leq 1,
\end{gathered}
$$

де $x$ і $y$ - відстані від головних осей інерції до розглядуваної точки перерізу; $w(t)_{s}$ - параметр пошкодження, зменшення статичного моменту опору перерізу, долі від одиниці; $w(t)_{\text {кIIC }}$ - параметр пошкодження структури матеріалу у вигляді зменшення значення критичного коефіцієнта інтенсивності напружень поздовжнього зсуву, що змінюється в часі, долі від одиниці; $\left[K_{\text {IIIC }}\right]$ - критичне значення коефіцієнта інтенсивності напружень поздовжнього зсуву у відповідності з рис. 2, МП $\times(\mathcal{M})^{0,5}$, приймаються за результатами випробувань зразків або за даними [3]; $w(t)_{W}$ - параметр пошкодження, зменшення моменту опору перерізу на час експлуатації $t$, долі від одиниці.

При цьому, у розрахунковому перерізі, розташованому на опорах нерозрізних балок, у формулі (9.4) замість коефіцієнта 0,87 слід приймати коефіцієнт $0,77$. 


\section{WLA 1 Mah}
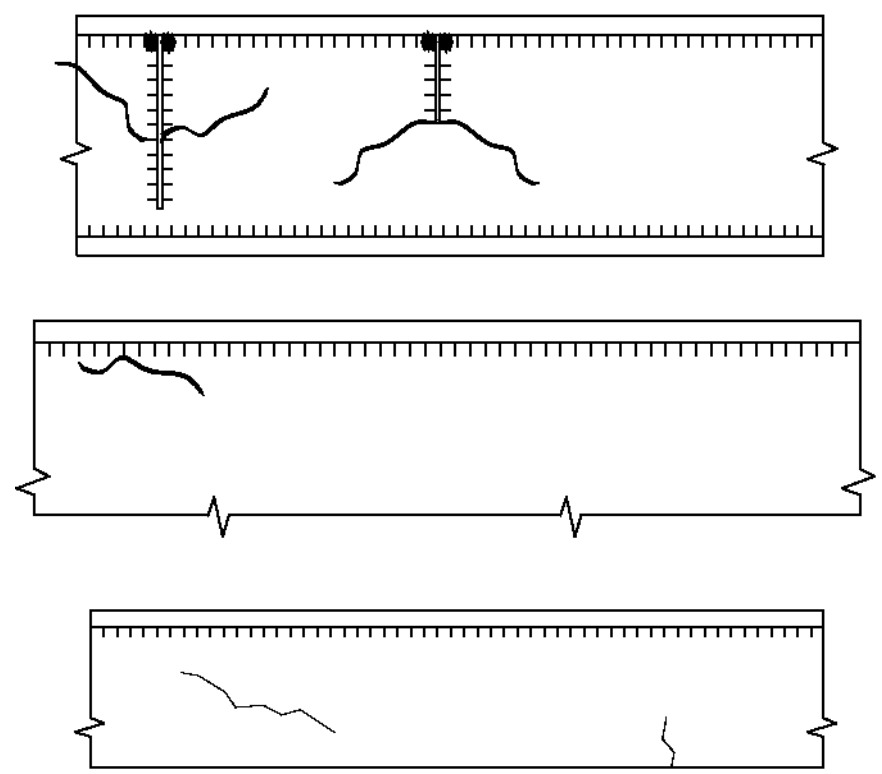

Рис.1. Пошкодження в балках у вигляді тріщин.

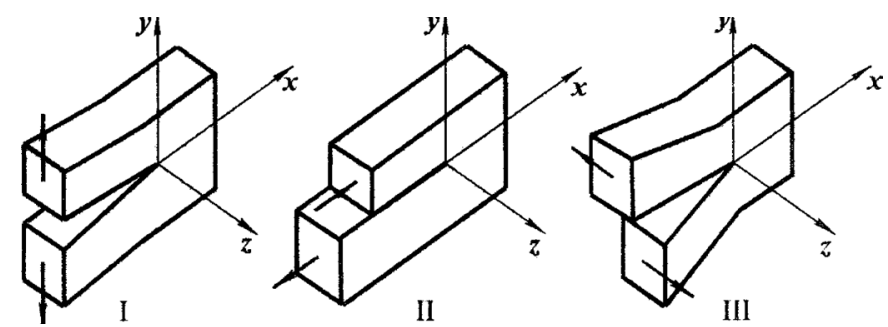

Рис.2. Різновиди переміщення берегів тріщин і відповідно різновиди руйнувань (I - нормального відриву,

II - поперечного зсуву, III - поздовжнього зсуву).

9.3.3 Міцність стиснутої зони стінок балок кранових колій, що розраховуються на утомленість, для кранів груп режимів роботи 7К (у цехах металургійних виробництв) і 8 К за ГОСТ 25546, виконаних зі сталі з межею текучості до $440 \mathrm{H} / \mathrm{мм}^{2}$ (рис. 9.1) слід виконувати за формулами:

$$
\begin{gathered}
\frac{\gamma_{n} \times \beta_{k}}{R_{y} \times\left(1-\omega(t)_{R}\right.} \times \sqrt{\left(\sigma_{x}+\sigma_{l o c, x}\right)^{2}-\left(\sigma_{x}+\sigma_{l o c, x}\right) \sigma_{l o c, y}+\sigma_{l o c, y}^{2}+3\left(\tau_{x y}+\tau_{l o c, x y}\right)^{2}} \leq 1 ; \\
\frac{\gamma_{n}}{R_{y} \times\left(1-\omega(t)_{R}\right)} \times\left(\sigma_{x}+\sigma_{l o c, x}\right) \leq 1 ; \\
\frac{\gamma_{n}}{R_{y} \times\left(1-\omega(t)_{R}\right)} \times\left(\sigma_{f y}+\sigma_{l o c, y}\right) \leq 1 ; \\
\frac{\gamma_{n}}{R_{y} \times\left(1-\omega(t)_{R}\right)} \times\left(\tau_{x y}+\tau_{l o c, x y}+\tau_{f, x y}\right) \leq 1,
\end{gathered}
$$

де умовні позначення такі самі, як в [1], $\beta$ - коефіцієнт, який приймається таким, що дорівнює 0,77 - при розрахунку перерізів, розташованих на опорах нерозрізних балок та 0,87 - при розрахунку розрізних балок у прольоті;

$$
\begin{gathered}
\sigma_{x}=\frac{M_{x}(t)}{I_{x n} \times\left(1-\omega(t)_{I}\right)} \times y ; \\
\sigma_{l o c, x}=0,25 \sigma_{l o c, y} \\
\sigma_{l o c, y}=\frac{\gamma_{f} \gamma_{f 1} F}{l_{e f} t_{w}} ; \\
\sigma_{f y}=\frac{2 M_{t}(t) \times t_{w}}{I_{\Sigma f} \times\left(1-\omega(t)_{I}\right)} ; \\
\tau_{x y}=\frac{Q_{y}}{t_{w} h_{w}} \\
\tau_{l o c, x y}=0,3 \sigma_{l o c, y} \\
\tau_{f, x y}=0,25 \sigma_{f y} .
\end{gathered}
$$
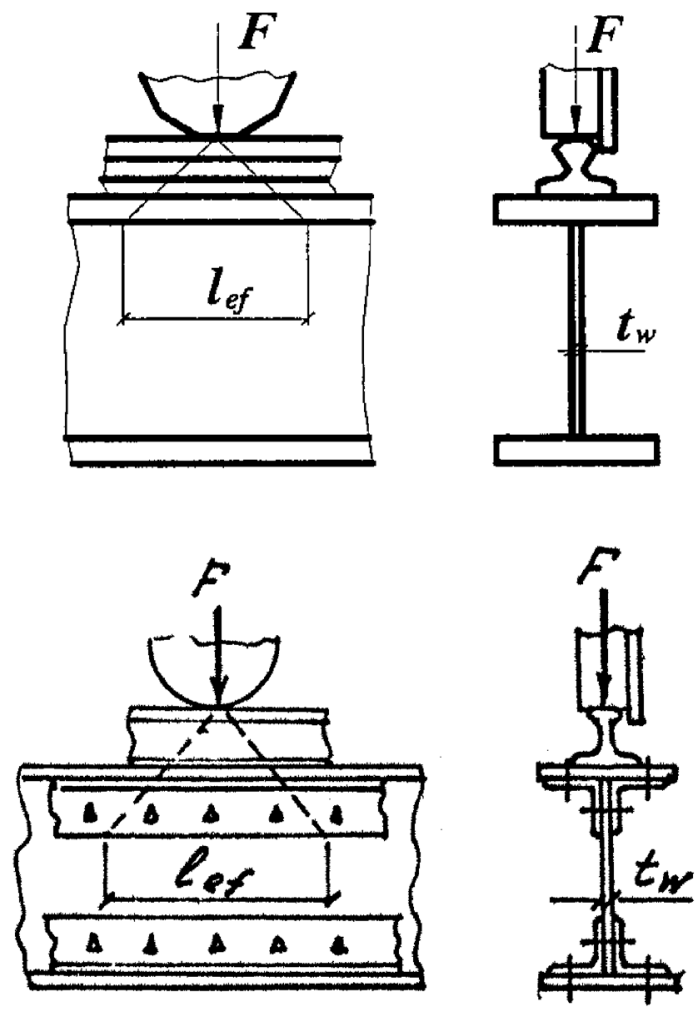

Рис.9.1. Схема розподілення зосередженого навантаження на стінку балки.

У формулах (9.26) позначено: $M_{x}(t)$ і $Q(t)$ - відповідно згинальний момент і поперечна сила у перерізі балки від розрахункового навантаження, що визначається згідно 3 ДБН В.1.2-2:2006; $h_{w}-$ висота стінки поперечного перерізу балки; $y$ - відстань до розглядуваної точки стінки балки, що дорівнює половині їі висоти; $\gamma_{f 1}$ - коефіцієнт збільшення зосередженого вертикального навантаження від одного колеса крана, що приймається згідно 3 ДБН В.1.2-2:2006; $F$ - розрахункове експлуатаційне значення зосередженого вертикального навантаження від одного колеса крану; $l_{e f}$ - умовна довжина ділянки розподілу зосередженого навантаження, що визначається згідно з вимогами п. 9.2.2; $M t$ - місцевий крутний момент, що визначається за формулою: 


\section{malla}

$$
M_{t}=\gamma_{f} \gamma_{f 1} F e+0,75 Q_{t}\left(h_{r}+t_{f}+b\right)
$$

де $e$ - умовний ексцентриситет, що приймається рівним 15 мм; $Q_{t}$ - розрахункове горизонтальне навантаження (бічна сила), що спрямоване впоперек до напрямку кранової колії, обумовлене перекосами мостових кранів і непаралельністю кранових шляхів, та приймається відповідно до ДБН В.1.2-2:2006; $h_{r}$ - висота балки кранової колії; $t_{f}$ - сумарна товщина поясних листів; $b$ - ширина вертикальної полиці поясного кутика (для балок 3 болтовими фрикційними поясними з'єднаннями);

$$
I_{\Sigma f}=I_{t}+I_{f}=I_{t}+0,33 \sum_{i} b_{i} t_{i}^{3},
$$

$I_{\Sigma f}$ - сума моментів інерції при крученні відповідно рейки $I_{t}$ і поясу $I_{f} ; b_{i}$ і $t_{i}-$ відповідно ширина і товщина листових елементів, що утворюють верхній пояс, у тому числі полиць і поясних кутиків.

Усі складові напруженого стану у формулах (9.22) - (9.26) слід приймати зі знаком “плюс". Окрім цього, при обчисленні значень напружень $\sigma_{x}$ і $\tau_{x y}$ необхідно враховувати вимоги п. 9.2.2.

9.3.4 Розрахунок на міцність підвісних балок кранових колій (монорейок) слід виконувати 3 урахуванням місцевих нормальних напружень від тиску колеса крану, що спрямовані вздовж та впоперек до осі балки та не діють одночасно.

9.3.5 Розрахунок на міцність бісталевих балок кранових колій двотаврового перерізу з двома осями симетрії без гальмових конструкцій для кранів груп режимів роботи 1 К - 5 К за ГОСТ 25546 при $r=R_{y f} / R \leq 1,5$ допускається виконувати за формулою (9.19),

- при згині у двох головних площинах

$$
\begin{gathered}
\frac{\gamma_{n} \times M_{x}(t)}{C_{x r} \times \beta_{r} \times W_{x n} \times\left(1-\omega(t)_{W}\right) \times R_{y W} \times\left(1-\omega(t)_{R}\right) \times \gamma_{C}} \pm \\
\pm \frac{\gamma_{n} \times M_{y}(t)}{C_{y r} \times W_{y n} \times\left(1-\omega(t)_{W}\right) \times R_{y f} \times\left(1-\omega(t)_{R}\right) \times \gamma_{c}} \leq 1
\end{gathered}
$$

у якій слід приймати:

$$
c_{x r}=\frac{\alpha_{f} \times r+0,25-0,0833 / r^{2}}{\alpha_{f}+0,167},
$$

де $\alpha_{f}=A_{f} / A_{W}, r=R_{y f} / R_{y W} ; \beta-$ коефіцієнт, що приймається у відповідності з п. 9.2.8 [1], $M_{y}(t)$ - згинальний момент у горизонтальній площині, що повністю передається на верхній пояс балки; $W_{y n}=W_{y n}$ - момент опору перерізу верхнього поясу балки відносно осі $y-y ; c_{y r}-$ коефіцієнт, який приймається таким, що дорівнюе 1,15 .

Розрахунок на міцність стінок бісталевих балок кранових колій слід виконувати відповідно до вимог п. 9.3.2.

9.4 Розрахунок на загальну стійкість елементів суцільного перерізу, що згинаються

9.4.1 Розрахунок на загальну стійкість двотав- рових балок 1-го класу, а також бісталевих балок 2-го класу при виконанні вимог п. 9.2.1 і п. 9.2.8 необхідно виконувати за формулами:

- при згині у площині стінки, що збігається 3 площиною симетрії перерізу:

$$
\frac{\gamma_{n} M_{x}(t)}{\varphi_{b} W_{C X}\left(1-\omega(t)_{W}\right) R_{y}\left(1-\omega(t)_{R}\right) \gamma_{C}} \leq 1
$$

- при згині у двох головних площинах:

$$
\begin{aligned}
& \frac{\gamma_{n} M_{x}(t)}{\varphi_{b} W_{C X}\left(1-\omega(t)_{W}\right) R_{y}\left(1-\omega(t)_{R}\right) \gamma_{C}} \pm \\
& \pm \frac{\gamma_{n} M_{y}(t)}{W_{y}\left(1-\omega(t)_{W}\right) R_{y}\left(1-\omega(t)_{R}\right) \gamma_{c}} \leq 1
\end{aligned}
$$

У формулах (9.28) і (9.29) позначено: $W_{x}$ - момент опору перерізу відносно осі $x-x$, обчислений для стиснутого поясу елемента; $W_{y}$ - момент опору перерізу відносно осі $y-y$, що співпадає з площиною згину; $\varphi_{B}-$ коефіцієнт, що враховує викривлення стінки балки і приймається в [2] меншим з:

$$
\begin{gathered}
\varphi_{B 1}=\varphi ; \\
\varphi_{B 2}=A_{1} \times\left(1-B_{1} \times \overline{v_{0}}\right) ; \\
\varphi_{B, 3}=A_{2} \times\left(1+B_{2} \times \overline{v_{0}}-C_{2} \times\left|\overline{u_{0}}\right|\right),
\end{gathered}
$$

в залежності від умовної гнучкості в площині симетрії листа

$$
\overline{\lambda_{x}}=\frac{l_{0 x}}{i_{x}} \sqrt{\frac{R_{y}\left(1-\omega_{R}\right)}{E\left(1-\omega_{E}\right)}},
$$

і умовної відносної стрілки викривлення листа (рис. 3)

$$
\overline{u_{0}}=\frac{f_{x 0}}{l_{x 0}} \sqrt{\frac{E\left(1-\omega_{E}\right)}{R_{y}\left(1-\omega_{R}\right)}}, \overline{v_{0}}=\frac{f_{y 0}}{l_{y 0}} \sqrt{\frac{E\left(1-\omega_{E}\right)}{R_{y}\left(1-\omega_{R}\right)}} .
$$

Коефіцієнти А1, А2, В1, В2, С2, визначаються за табл. 1.

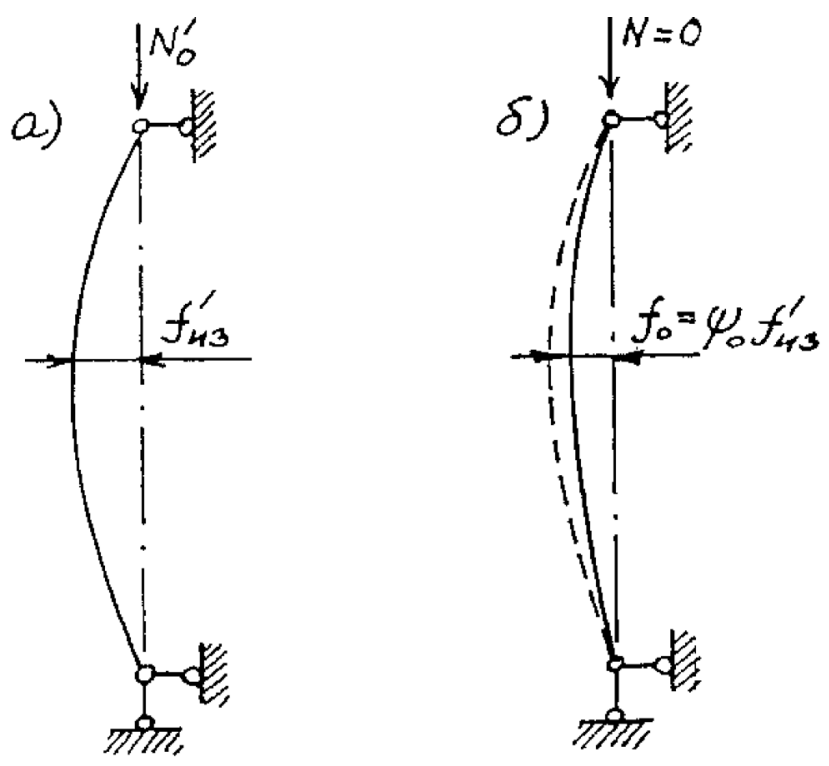

Рис.3. Визначення еквівалентного ексцентриситету. а - стан вимірювання; 6 - ненавантажений стан. 


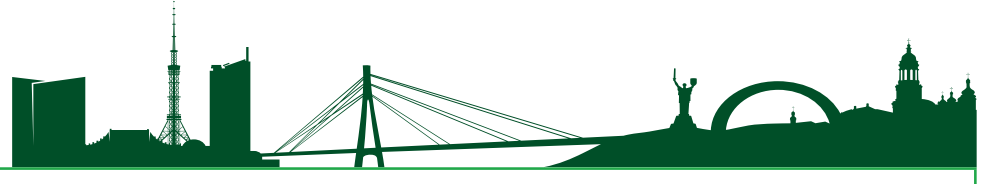

\begin{tabular}{|c|c|c|c|c|c|c|}
\hline \multirow[t]{2}{*}{$\overline{\lambda_{x}}$} & \multirow[t]{2}{*}{$\varphi$} & \multicolumn{5}{|c|}{$\begin{array}{c}\text { Переріз з листів } \\
\text { посилених ребрами. } \\
\text { Значення збільшені в } 1000 \\
\text { разів }\end{array}$} \\
\hline & & $\mathrm{A}_{1}$ & $\mathrm{~B}_{1}$ & $\mathrm{~A}_{2}$ & $\mathrm{~B}_{2}$ & $\mathrm{C}_{2}$ \\
\hline 0,5 & 971 & 966 & 401 & 951 & 160 & 358 \\
\hline 1,0 & 901 & 909 & 630 & 832 & 179 & 542 \\
\hline 1,5 & 826 & 775 & 601 & 711 & 158 & 634 \\
\hline 2,0 & 744 & 710 & 581 & 635 & 178 & 633 \\
\hline 2,5 & 653 & 571 & 512 & 481 & 96 & 520 \\
\hline 3,0 & 562 & 429 & 329 & 395 & 66 & 448 \\
\hline 3,5 & 476 & 381 & 317 & 320 & 44 & 358 \\
\hline 4,0 & 401 & 303 & 225 & 264 & 26 & 292 \\
\hline 4,5 & 340 & 260 & 190 & 219 & 18 & 235 \\
\hline 5,0 & 289 & 229 & 163 & 184 & 12 & 192 \\
\hline 5,5 & 247 & 212 & 152 & 159 & 8 & 162 \\
\hline 6,0 & 211 & 205 & 136 & 136 & 3 & 135 \\
\hline
\end{tabular}

Для бісталевих балок у формулах (9.28) i (9.29), а також при визначені $\varphi_{B}$ слід замінити $R_{y}$ на $R_{y f}$.

16.4 Поясні з'єднання в балках, що знаходяться в експлуатаціï

16.4.1 Зварні і фрикційні поясні з'єднання двотаврової балки, що знаходяться в експлуатації, слід розраховувати на статичну міцність за формулами, наведеними в таблиці. 16.6, і на опір крихкому руйнуванню за формулами, наведеними в табл. 16.7. При прикладанні нерухомого зосередження навантаження до верхнього поясу балки за відсутності поперечних ребер жорсткості у місцях прикладення навантаження, а також при прикладанні нерухомого зосередження навантаження до нижнього поясу незалежно від наявності ребер жорсткості в місцях прикладання навантаження поясні з'єднання слід розраховувати як для рухомого навантаження. Зварні шви, що виконані з проваром на всю товщину стінки, слід вважати однаково міцними зі стінкою.

16.4.2 У балках 3 фрикційними поясними з'єднаннями з багатолистовими поясними пакетами прикріплення кожного 3 листів у розрахунковому перерізі, розташованому за місцем свого теоретичного обриву, слід розраховувати на половину зусилля, що може бути сприйняте поперечним перерізом листа. Прикріплення кожного листа у розрахунковому перерізі, розташованому на ділянці між дійсним місцем його обриву і місцем обриву попереднього листа, слід розраховувати на повне зусилля, що може бути сприйняте поперечним перерізом листа.

Розрахунок на витривалість і циклічну тріщиностійкість болтових та фрикційних з'єднань викладено в $[4,5]$. поясних з'єднань у складаних балках

\begin{tabular}{|c|c|c|c|}
\hline $\begin{array}{c}\text { Характер } \\
\text { навантаження }\end{array}$ & Поясні з’еднання & \multicolumn{2}{|l|}{ Розрахункова формула } \\
\hline \multirow[t]{3}{*}{ Нерухоме } & \multirow[t]{2}{*}{ Зварні } & $\frac{T(t) \gamma_{n}}{n \beta_{f} k_{f} R_{w f} \times\left(1-\omega_{R}\right) \times \gamma_{C}} \leq 1$ & $(16.19)$ \\
\hline & & $\frac{T(t) \gamma_{n}}{n \beta_{z} k_{f} R_{w z} \times\left(1-\omega_{R}\right) \times \gamma_{C}} \leq 1$ & $(16.20)$ \\
\hline & Фрикційні & $\frac{T(t) \times s \times \gamma_{n}}{Q(t) \times k \times \gamma_{C}} \leq 1$ & $(16.21)$ \\
\hline \multirow[t]{3}{*}{ Рухоме } & \multirow[t]{2}{*}{ Зварні (двосторонні шви) } & $\frac{\gamma_{n} \sqrt{T^{2}(t)+V^{2}(t)}}{2 \beta_{f} k_{f} R_{w f} \times\left(1-\omega_{R}\right) \times \gamma_{C}} \leq 1$ & $(16.22)$ \\
\hline & & $\frac{\gamma_{n} \sqrt{T^{2}(t)+V^{2}(t)}}{2 \beta_{z} k_{f} R_{w z} \times\left(1-\omega_{R}\right) \times \gamma_{C}} \leq 1$ & $(16.23)$ \\
\hline & Фрикційні & $\frac{\gamma_{n} \times s \times \sqrt{T^{2}(t)+\alpha^{2} V^{2}(t)}}{Q_{b h}(t) \times k \times \gamma_{C}} \leq 1$ & $(16.24)$ \\
\hline \multicolumn{4}{|c|}{$\begin{array}{l}\text { Позначення, прийняті в табл. 16.6: } T(t)=\frac{Q(t) \times S \times\left(1-\omega_{S}\right)}{I \times\left(1-\omega_{I}\right)}-\text { погонне зусилля зсуву поясу, } \\
\text { що викликане поперечною силою } Q(t) \text { (тут } \mathrm{S}-\text { статичний момент брутто поясу балки } \\
\text { відносно нейтральної осі); } \omega_{s,} \omega_{I}-\text { параметри пошкодження відповідно статичного } \\
\text { моменту і моменту інерції перерізу, долі від одиниці; } n-\text { кількість кутових швів: при } \\
\text { двосторонніх кутових швах у поясних з'єднаннях }-n=2, \text { при односторонніх }-n=1 ; Q_{b h}(t) \text { і } \\
k-\text { величини, що визначаються згідно з п. } 16.3 .4 ; k_{f}-\text { величини катету зварного шва }(\text { м), } \\
V(t)=\gamma_{f} \gamma_{f 1} F_{n}(t) / l_{e f}-\text { погонний тиск від зосередженого вантажу } F_{n}, \text { що визначається } 3 \\
\text { урахуванням вимог п. } 9.2 .2 \text { і п. } 9.2 .3 \text {, при цьому } l_{e f} \text { виміряється в }\left(\text { м); } \gamma_{f}, \gamma_{f l}-\text { коефіцієнти }\right. \\
\text { надійності за навантаженням, що приймаються згідно з ДьН В. } 1.2-2: 2006 \text { (для нерухомих } \\
\left.\text { вантажів } \gamma_{f l}=1\right) ; s-\text { крок поясних болтів (м); } \alpha-\text { коефіцієнт, який приймається таким, що } \\
\text { дорівнює: } \alpha=0,4-\text { за наявності навантаження, прикладеного до верхнього поясу балки, до } \\
\text { якого пристругана стінка, і } \alpha=1,0-\text { за відсутності пристругування стінки або за наявності } \\
\text { навантаження, прикладеного до верхнього поясу. }\end{array}$} \\
\hline
\end{tabular}

Таблиия 16.7 Формули для розрахунку на опір крихкому руйнуванню поясних з'єднань у складаних балках

\begin{tabular}{|c|c|c|c|}
\hline $\begin{array}{c}\text { Характер } \\
\text { навантаження }\end{array}$ & Поясні з'єднання & \multicolumn{2}{|l|}{ Розрахункова формула } \\
\hline \multirow[t]{3}{*}{ Нерухоме } & \multirow[t]{2}{*}{ Зварні } & $\frac{\gamma_{n} T(t) \sqrt{\pi l}}{n \beta_{f} k_{f}\left[K_{I I C}\right]_{w f} \times\left(1-\omega_{K I I C}\right) \times \gamma_{C}} \leq 1$ & $(16.25)$ \\
\hline & & $\frac{\gamma_{n} T(t) \sqrt{\pi l}}{n \beta_{z} k_{f}\left[K_{I C}\right]_{w z} \times\left(1-\omega_{K I C}\right) \times \gamma_{C}} \leq 1$ & $(16.26)$ \\
\hline & Фрикційні & Розрахунок не виконується & \\
\hline \multirow[t]{3}{*}{ Рухоме } & \multirow[t]{2}{*}{ Зварні (двосторонні шви) } & $\frac{\gamma_{n} \sqrt{T^{2}(t)+V^{2}(t)} \times \sqrt{\pi t}}{2 \beta_{f} k_{f}\left[K_{I I C}\right]_{w f} \times\left(1-\omega_{K I I C}\right) \times \gamma_{C}} \leq 1$ & $(16.27)$ \\
\hline & & $\frac{\gamma_{n} \sqrt{T^{2}(t)+V^{2}(t)} \times \sqrt{\pi t}}{2 \beta_{z} k_{f}\left[K_{I C}\right]_{w z} \times\left(1-\omega_{K I C}\right) \times \gamma_{C}} \leq 1$ & $(16.28)$ \\
\hline & Фрикційні & Розрахунок не виконується & \\
\hline \multicolumn{4}{|c|}{ 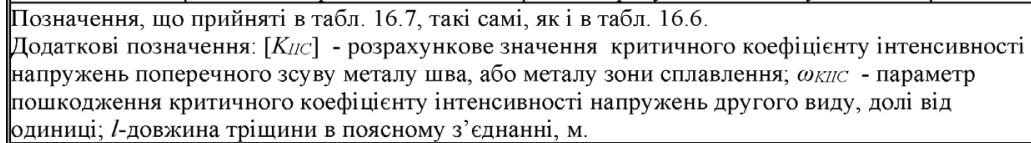 } \\
\hline
\end{tabular}

Розрахунок елементів сталевих конструкцій, на які спираються балки кранових колій на статичну міцність і опір крихкому руйнуванню, виконується за формулами [10]. Розрахунок вузлів кріплення сталевих конструкцій, на які спираються балки кранових колій на опір крихкому руйнуванню, виконується за формулами [11].

\section{ВИЗНАЧЕННЯ СТРОКУ САУЖБИ КРАНОВИХ КОАІЙ ЗА КІАЬКІСТЮ ЦИКАІВ I ВЕАИЧИНОЮ НАВАНТАЖЕННЯ В КОЖНОМУ ЦИКАI}

Строк служби кранових колій до початку експертних обстежень - календарна тривалість від початку експлуатації до заступлення строку, вказаного в службовій або нормативній документації, після закінчення якого повинні виконуватися 
експертні обстеження. Цей строк служби менше призначеного строку служби або ресурсу. Характеристичне число $(N)$ - безрозмірна величина, що є мірою напрацювання колії, яка визначається як сума кубів відношення мас вантажів, що піднімаються, до максимальної вантажопідйомності колії:

$$
N=\sum_{i=1}^{C}\left[Q_{i} / Q_{\max }\right]^{3}
$$

де: $Q_{\max }$ - максимально допустиме навантаження на кранову колію; $Q_{i}$ - навантаження на кранову колію на і-тому циклі; $C$ - кількість робочих циклів крана, виконаних від початку експлуатації.

Коефіцієнт вичерпання ресурсу $\left(K_{p}\right)$ визначається як відношення:

$$
K_{P}=N_{T} / N_{H},
$$

де $N_{T}$ - безрозмірна величина, яка $є$ мірою використання колії на час, що плине, та визначається з урахуванням усіх робочих циклів, виконаних від початку експлуатації крану і величини усіх вантажів в кожному робочому циклі; $N_{H}$ - безрозмірна величина, яка $є$ мірою напрацювання колії, на яку вона розрахована, визначається з умови неперевищення межі витривалості сталі будь-якого елементу колії (на межі витривалості приймається $\left.N_{H}=1 \times 106\right)$, або не перевищення межі пропорційності сталі (на межі пропорційності $N_{H}=1 \times 104$ ), або не перевищення межі текучості сталі (на межі текучості $\left.N_{H}=1 \times 103\right)$.

У випадку, коли $K_{p}=1$, строк служби кранових колій вичерпано.

\section{ПРИБАИЗНА ОЦІНКА ВИТРИВАЛОСТІ КРАНОВИХ КОАІЙ НАВАНТАЖЕННЯ РЕЙКОВОГО ТРАНСПОРТУ НА КРАНОВУ РЕЙКУ}

Для оцінки витривалості навантаження слід приймати різними для локальних та глобальних розрахунків.

При глобальних розрахунках розмах напружень в елементі рейкової колії визначається від дії одного крану, при цьому довжина ділянки лінії впливу одного знаку має бути більше за відстань між колесами крану. При локальних розрахунках оцінюють дію вагонних осей. Розрахункове навантаження на вісь колеса крану $P_{f}$ слід приймати за формулою:

$$
P_{f}=P_{n} \times \gamma_{f} \times(1+\mu),
$$

де $P_{f}$ - характеристичне навантаження на вісь; $\gamma_{f}$ - коефіцієнт надійності за навантаженням: 1, 2 для глобальних розрахунків, де навантаженням $є$ кран; 1,0 - для локальних розрахунків, де навантаженням є вісь колеса крану; $(1+\mu)$ - динамічний коефіцієнт, що дорівнює 1,0 (якщо колія в нормальному стані).

\section{РОЗРАХУНОК КІАЬКОСТІ ЦИКАІВ НАВАНТАЖЕННЯ НА КРАНОВУ РЕЙКУ}

Розрахунок кількості циклів розмаху напружень в крановій колії аналогічний до розрахунку кількості циклів від рейкового транспорту та від автомобільного навантаження. Загальну кількість циклів від проїзду крану по крановій колії за період проектного строку служби визначають за формулою [6]:

$$
N=n_{D} \times n_{Y} \times n_{C} \times n_{T} \leq 1 \times 10^{8},
$$

де $n_{D}$ - кількість днів у році, $n_{y}$ - проектний строк служби кранової колії в роках; $n_{C}-$ кількість циклів (коліс крану з одного боку) від проходу одного крану; $n_{T}$ - середня денна кількість проходів крану в одному напрямку.

\section{ПОРІГ ВИТРИВААОСТІ КРАНОВИХ РЕЙОК}

Визначення розрахунком витривалості з'єднання елементів кранових колій виконується аналогічно [6] за формулою:

$$
\Delta \sigma \leq \Delta \sigma_{R, n} /\left(\gamma_{\mathrm{fM}} \times \gamma_{r}\right),
$$

де $\Delta \sigma$ - розрахунковий розмах діючих напружень від розрахункових навантажень; $\Delta \sigma_{R, n}-$ поріг витривалості елемента в залежності від кількості циклів навантажень; $\gamma_{f M}-$ коефіцієнт надійності порогу витривалості дорівнює: 0,85 - для елементів, руйнація яких не призведе до руйнування кранової колії; 1,00 - для ключових елементів кранової колії; $\gamma_{r}$ - коефіцієнт відповідальності, що дорівнює: 1,00 для елементів, руйнація яких не призведе до руйнування кранової колії; 1,05 - для ключових елементів.

Розмах напружень знаходять за формулою (2) як різницю між найбільшими і найменшими напруженнями при лінійному аналізі. При цьому розтяг має становити не менше ніж $1 / 3$ загального розмаху напружень:

$$
\Delta \sigma=\sigma_{\max }-\sigma_{\min }, \Delta \tau=\tau_{\max }-\tau_{\min } .
$$

Поріг витривалості $\Delta \sigma_{R, n}$ знаходять, базуючись на значеннях порогів витривалості $\Delta \sigma_{C}$ або $\Delta \tau_{C}$ для 2 млн. циклів.

При кількості циклів менше ніж 2 млн. відповідний поріг витривалості $\Delta \sigma_{R, n}$ обчислюється за формулою:

$$
\Delta \sigma_{R, n}=\frac{\Delta \sigma_{C}}{\left(N_{i} / 2000000\right)^{1 / 3}} \cdot
$$

При кількості циклів від 2 млн. до 5 млн. поріг витривалості $\Delta \sigma_{R, n}=\Delta \sigma_{D}$ знаходять за формулою: 


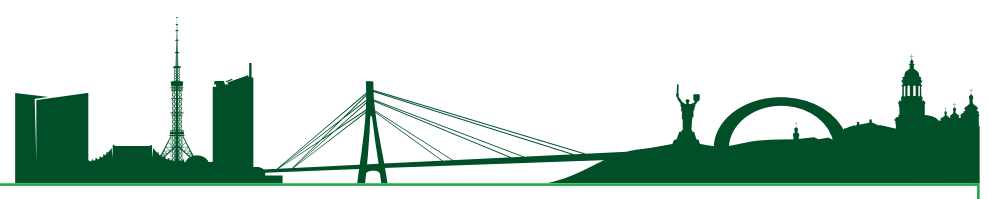

$$
\Delta \sigma_{D}=\frac{\Delta \sigma_{C}}{(5000000 / 2000000)^{1 / 3}}=0,737 \times \Delta \sigma_{C} .
$$

При кількості циклів більше 5 млн. відповідний поріг витривалості знаходять за формулою:

$$
\Delta \sigma_{R, n}=\frac{\Delta \sigma_{D}}{\left(N_{i} / 5000000\right)^{1 / 5}}=0,735 \frac{\Delta \sigma_{C}}{\left(N_{i} / 5000000\right)^{1 / 5}} \cdot
$$

\section{ОЦІНКА ВИТРИВААОСТІ БААОК КРАНОВИХ КОАІЙ}

Оцінку витривалості елементів кранових рейок виконують, якщо відома категорія витривалості, розмах напружень $\sigma_{1}, \sigma_{2}, \ldots, \sigma_{i}$, і відповідна кількість циклів навантажень $n_{1}, n_{2}, \ldots, n_{i}$, використовуючи наступний алгоритм:

1. Знаходиться граничне значення циклів при заданому розмаху напружень за формулою (3) при числі циклів п менше 5 млн. і за формулою (4) при числі циклів більше, ніж 5 млн.

$$
\begin{gathered}
N_{i}=5000000 \times\left(\Delta \sigma_{C} / \Delta \sigma_{i}\right)^{3}, n \leq 5000000, \\
N_{i}=5000000 \times\left(\Delta \sigma_{D} / \Delta \sigma_{i}\right)^{5}, n>5000000, \\
\Delta \sigma_{D}=\frac{\Delta \sigma_{C}}{(5000000 / 2000000)^{1 / 3}}=0,737 \times \Delta \sigma_{C}
\end{gathered}
$$

У формулах значення $\Delta \sigma_{C}$ та $\Delta \sigma_{D}$ - пороги витривалості елемента при 2 і 5 млн. циклів відповідно.

2. Для оцінки витривалості використовують лінійний закон накопичення пошкоджень (Палгрена Мінера). А саме, сума відношення фактичної кількості циклів до граничної не повинна перевищувати одиниці.

$$
\frac{n_{1}}{N_{1}}+\frac{n_{2}}{N_{2}}+\ldots+\frac{n_{i}}{N_{i}} \leq 1
$$

де $n_{l}, n_{2}, \ldots, n_{i},-$ кількість циклів при заданих розмахах напружень $\sigma_{l}, \sigma_{2}, \ldots, \sigma_{i}: N_{l}, N_{2}, \ldots, N_{i}$ - граничні значення циклів при заданих розмахах напружень.

Точна оцінка витривалості зварних з'єднань елементів кранових колій викладена в [3].

\section{ПРИКААД РОЗРАХУНКУ ВИТРИВААОСТІ БАЛОК КРАНОВИХ КОАІЙ}

Розглянемо витривалість балок кранових колій Нового безпечного конфайменту (НБК). У відповідності 3 [7] система основних кранів (СОК) НБК складається 3 двох кранів, що переміщуються в напрямку схід-захід на довжину ходу 148,35м; кожний кран повинен переміщуватися на відстань
122,2 м. Мінімальна допустима відстань між кранами при нормальному режимі експлуатації становить 11,8 м. Зона захоплення СОК, при нормальному режимі експлуатації становить 130,5 м. Система основних кранів забезпечена трьома візками: один стандартний вантажний візок вантажопідйомністю 50 т, другий - спеціально безпечний вантажний візок вантажопідйомністю 40 т, третій візок обладнаний мобільною інструментальною платформою за допомогою кроквяної

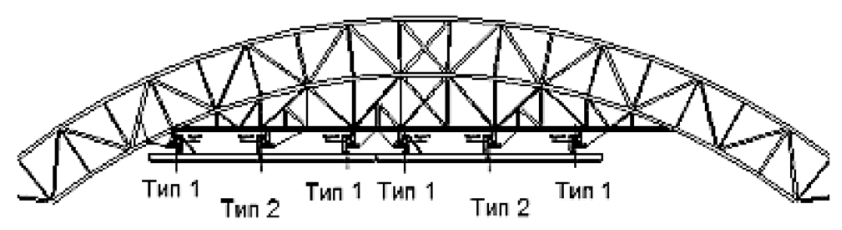

Рис.4. Схема кранових колій НБК.

ферми. Схема кранових колій в перерізі показана на рис. 4.

Балки кранових колій підвішені до кранової платформи. Балки вирішені у вигляді шести незалежних ліній. Балки кранових колій прийняті у вигляді коробчастого перерізу висотою 1,3 м, шириною 0,96 м (рис. 5).

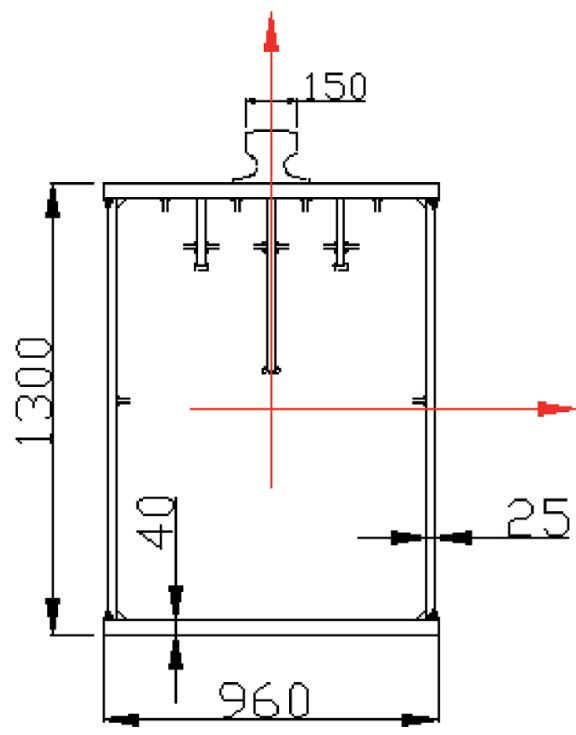

Рис.5. Переріз балки кранової колії

Балки кранових колій спираються на опори в межах секцій, як показано на рис. 6.

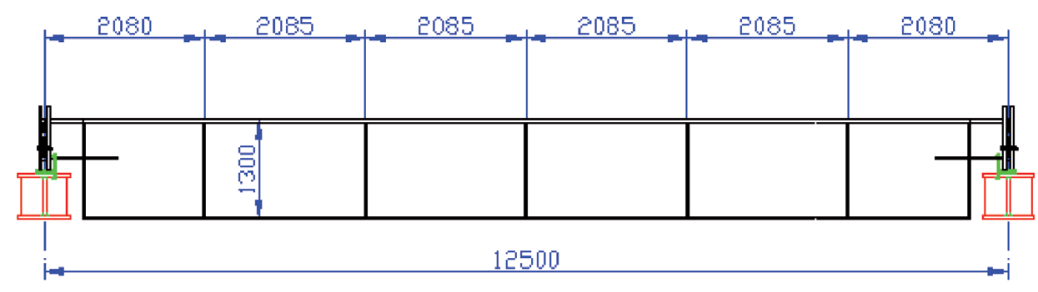

Рис.6. Секції балок кранових колій 
Таблиия 2.

\begin{tabular}{|l|c|l|}
\hline \multicolumn{1}{|c|}{ Назва вимоги } & Кран 6К (А6) & \multicolumn{1}{|c|}{ Посилання } \\
\hline $\begin{array}{l}\text { Встановлено безвідмовне } \\
\text { напрацювання не менше } \\
\text { (цикли) }\end{array}$ & 64000 & $\begin{array}{l}\text { ГОСТ 27584-88 Таблиця 2 i } \\
\text { додаток 4, 3-й абзац. }\end{array}$ \\
\hline $\begin{array}{l}\text { Напрацювання на відмову, не } \\
\text { менше (циклів) }\end{array}$ & 11000 & $\begin{array}{l}\text { ГОСТ 27584-88 Таблиця 2 i } \\
\text { додаток 4, 2-й абзац. }\end{array}$ \\
\hline
\end{tabular}

МITEPATУPA

1. Сталеві конструкції. Норми проектування: ДБН В.2.6- 198:2014. - [Чинні від 2015-01-01]. - К.: Мінрегіонбуд України, 2014. V, 199 с. - (Будівельні норми України).

2. Оцінка технічного стану сталевих конструкцій виробничих будівель і споруд, що знаходяться в експлуатації: ДБН В 362-92. [Чинні від 1992-07-01]. - К.: Державний комітет України в справах архітектури, будівництва та охорони історичного середовища, 1995. - 47 с. - (Будівельні норми України).

3. Матченко T.I. Розрахунок зварних елементів сталевих конструкцій на витривалість і циклічну тріщиностійкість / Матченко T.I., Шаміс А.Б., Матченко П.Т. // Будівництво України, 2015. - № 1. - С. 37-44.

4. Матченко T.I. Методика розрахунку довговічності фрикційних з'єднань сталевих конструкцій / Матченко Т.І., Шаміс А.Б., Матченко П.Т. // Будівництво України, 2015. - № 2-3. - C. 44-51.

5. Шаміс А.Б. Розрахунок болтових з'єднань на циклічну тріщиностійкість і крихку міцність / Шаміс А.Б. // Будівництво України, 2016. - № 1. - С. 27-34.

6. Мости і труби. Сталеві конструкції. Правила проектування. Споруди транспорту. (Частина 1): ДБН В.2.3-26:2010. - [Чинні від 2011-10-01]. - К.: Мінрегіонбуд України, 2011. - IV, 195 с. - (Будівельні норми України).

7. SIP N TE 22 B 104-REQ 001 04. Система основных кранов. Спецификация на закупку.

$$
\frac{64000}{3511659}+\frac{11000}{1035881}=0,02884 \leq 1 .
$$

Результати розрахунків добре узгоджуються 3 результатами [9], за якими імовірність відмови становить 0,031 .

\section{ВИСНОВКИ}

1. Отримано співвідношення для розрахунків на витривалість, міцність та опір крихкому руйнуванню балок кранових колій, що мають тріщини, або в матеріалі яких відбулися процеси старіння.

2. Отримані співвідношення можуть бути застосовані при визначенні придатності до експлуатації існуючих конструкцій та для актуалізації ДБН В.2.6-198. 


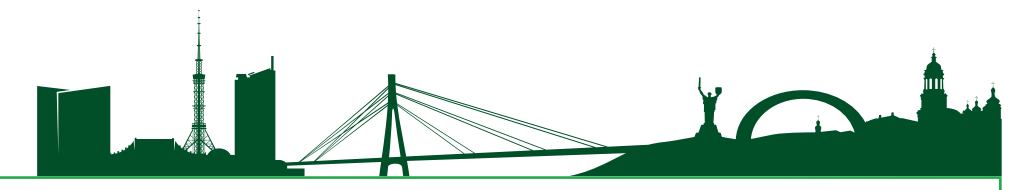

11. Матченко T.I. Розрахунок вузлів ферм на опір крихкому руйнуванню / Матченко T.I. // Будівництво України, 2016. - № 4. - С. 3341.

\section{REFERENCES}

1. Stalevi konstruktzii. Normu proektuvannya [Steel structures. Design norms]. (2014). DBN V.2.6-198:2014 from 01 $1^{\mathrm{t}}$ January 2015. Kyiv: Ministry of Regional Development, Construction and Housing and Communal Services of Ukraine [in Ukrainian].

2. Otzinka tehnichnogo stany stalevuh konstrukzij vurobnuchuh budivel i sporud, sho znahodyatsa v ekspluatazii [Evaluation of the technical condition of steel constructions of industrial buildings and structures in use]. (1995). DBN 362-92 from 01 ${ }^{\mathrm{t}}$ July 1992. Kyiv: State Committee of Ukraine in architecture, construction and historical monuments protection [in Ukrainian].

3. Matchenko T.I., Shamis L.B. \& Pervushova L.F. (2015). Rozrahunok zvarnuh elementiv stalevuh konstrukziy na vutruvalist i tziklichny trishunostijkist [Calculation of welded steel structure on endurance and cyclic endurance fracture]. Budivnytstvo Ukrainu. - Construction of Ukraine, 1, 37-44 [in Ukrainian].

4. Matchenko T.I., Shamis L.B. \& Pervushova L.F. (2015). Metoduka rozrahunku dovgovichnosti fruktziynuh zednan stalevuh konstruktziy [Methods of calculating the durability of friction connections of steel structures]. Budivnytstvo Ukrainy - Construction of Ukraine, 2-3, 44-51 [in Ukrainian].

5. Shamis L.B. (2016). Rozrahunok boltovuh zednan na tziklichny trishinostiykist i kruhky mitznist [Calculation of bolting joints on the brittle fracture resistance]. Budivnytstvo Ukrainy. - (Construction of Ukraine), 1, 27-34 [in Ukrainian].

6. Mostu i trubu. Stalevi konstruktzii. Pravula proektuvannya. Sporydu transporty. [Bridges and pipes. Steel structure. Planning rules. Building of transport (Part 1)]. (2011). DBN V.2.3-26-2010 from 01 ${ }^{\mathrm{t}}$ October 2011. Kyiv: Ministry of Regional Development, Construction and Housing and Communal Services of Ukraine [in Ukrainian].

7. SIP N TE 22 B 104-REQ 00104 Systema osnovnuh kranov. Spitsifikatzia na zakupky [Main cranes system. Purchasing specification].

8. 99-925.100.010.OT04.01.02 Commissioning Stage-1 (CS-1), Licensing Package-5 (LP-5), Design, Main Structure and Main Cranes System, Volume 4, Architectural and
Construction solutions, Part 1, Explanatory Note, Book 2, Section 3. PC KIEP, 2011 [in Russian].

9. SIP N PA 22 D 104 PRO 003-D Main cranes system. Reliability and risk analysis work instruction [in Russian].

10. Matchenko T.I. (2016). Rozrahunok elementiv stalevuh konstruktziy, sho znahodyatsa v eksplyatatzii, na statuchny mitznist i opir kruhkomy ruynuvanny [Calculation of steel structures in use for static strength and resistance to brittle fracture]. Nauka ta budivnuztvo - Science and construction, Vol. 2(8), 28-34 [in Ukrainian].

11. MatchenkoT.I.(2016). Rozrahunok vuzliv ferm na opir kruhkomy ruinuvannu [Calculation of farm sites on the brittle strength]. Budivnytstvo Ukrainy - Construction of Ukraine, Vol. 4, 33-41 [in Ukrainian]. 